\title{
Quality of life of seniors living in the community and in long term care facilities: a comparative study ${ }^{1}$
}

\author{
Luciano Magalhães Vitorino² \\ Lisiane Manganelli Girardi Paskulin ${ }^{3}$ \\ Lucila Amaral Carneiro Vianna ${ }^{4}$
}

Objectives: to compare the perceptions of quality of life (QOL) and to identify factors associated with QOL among seniors living in the community in Porto Alegre, RS and institutionalized seniors from the countryside of Minas Gerais, Brazil. Method: this study used secondary data from two cross-sectional epidemiological studies. The sample consisted of 288 seniors living in the community and 76 institutionalized seniors. An instrument addressing socio-demographic data and the WHOQOL-BREF were administered. Results: bivariate analysis showed that age, gender, schooling, self-reported health, and leisure presented statistically significant differences between institutionalized and non-institutionalized seniors. The Psychological and Social Relationships domains also presented statistically significant differences. The variables that presented significant correlation in multivariate analysis in relation to the Psychological domain were education, assessments of health, leisure and in relation to the Social domain, education and age. Conclusion: being institutionalized did not influence the older adults' perceptions of QOL, but the socio-demographic characteristics and self-assessments of health did.

Descriptors: Quality of Life; Aging; Aged; Comparative Study.

\footnotetext{
${ }^{1}$ Supported by Conselho Nacional de Desenvolvimento Científico e Tecnológico (CNPq), process \# 138107/2009-2 and by Coordenação de Aperfeiçoamento de Pessoal de Nível Superior (Capes), process \# PQI 00050/03-2.

2 Doctoral Student, Escola Paulista de Enfermagem, Universidade Federal de São Paulo, Brazil.

${ }^{3}$ PhD, Adjunct Professor, Escola de Enfermagem, Universidade Federal do Rio Grande do Sul, Brazil.

${ }^{4}$ PhD, Full Professor, Escola Paulista de Enfermagem, Universidade Federal de São Paulo, Brazil.
} 


\section{Qualidade de vida de idosos da comunidade e de instituições de longa permanência: estudo comparativo}

Objetivos: comparar a percepção da qualidade de vida entre idosos da comunidade de Porto Alegre, RS, e idosos institucionalizados do interior de Minas Gerais e identificar fatores associados à qualidade de vida entre esses idosos. Método: trata-se de investigação que utilizou dados secundários, a partir de dois estudos epidemiológicos transversais. A amostra foi de 288 idosos da comunidade e 76 institucionalizados. Utilizaram-se instrumentos de caracterização sociodemográfica e Whoqol-bref para avaliação da qualidade de vida. Resultados: na análise bivariada, evidenciou-se que idade, sexo, escolaridade, autoavaliação de saúde e lazer apresentaram diferenças estatisticamente significantes entre ser institucionalizado ou não. Da mesma forma, os domínios de qualidade de vida psicológico e relações sociais apresentaram diferenças estatisticamente significantes. Na análise multivariada, as variáveis que permaneceram com correlação significante no domínio psicológico foram escolaridade, avaliação de saúde e lazer e no domínio relações sociais, escolaridade e idade. Conclusão: o fato de o idoso ser institucionalizado não influenciou na percepção da qualidade de vida dos idosos, mas, sim, as características sociodemográficas e de saúde.

Descritores: Qualidade de Vida; Envelhecimento; Idoso; Estudo Comparativo.

\section{Calidad de vida de los ancianos de la comunidad y en instituciones de larga estancia: estudio comparativo}

Objetivos: comparar la percepción de la calidad de vida (CV) entre ancianos de la comunidad en Porto Alegre / RS y ancianos institucionalizados en Minas Gerais e identificar factores asociados a la calidad de vida entre esos ancianos. Método: en esa investigación, se utilizaron datos secundarios a partir de dos estudios epidemiológicos transversales. La muestra fue de 288 ancianos de la comunidad y 76 institucionalizados. Se utilizaron instrumentos de caracterización sociodemográfica y WHOQOL-BREF para evaluación de la CV. Resultados: en el análisis bivariado, se evidenció que edad, sexo, escolaridad, auto evaluación de la salud y recreación mostraron diferencias estadísticamente significativas entre ser institucionalizado o no. Los dominios de CV Psicológico y Relaciones Sociales presentaron asociación. En el análisis multivariado, las variables que permanecieron con correlación en el Dominio Psicológico: escolaridad, evaluación de salud, recreación y, en el Dominio Relaciones Sociales, escolaridad, edad. Conclusión: ser institucionalizado no influyó en la percepción de la CV de los ancianos, mientras las características sociodemográficas y de salud influyeron.

Descriptores: Calidad de Vida; Envejecimiento; Anciano; Estudio Comparativo.

\section{Introduction}

Quality of Life (QOL) is a construct with different definitions because cultural, ethical, religious and personal aspects influence $\mathrm{QOL}$ and the way it is perceived $^{(1)}$. Despite differences in definitions, there is agreement among most authors that a multidimensional approach is required if one desires to assess $\mathrm{QOL}^{(1)}$.

$\mathrm{QOL}$ is based on both objective and subjective parameters. The subjective parameters include wellbeing, happiness, and personal achievement, among others, while objective parameters are related to the satisfaction of basic needs and those that emerge in a given social structure. The objective parameters are not subject to observer bias, while subjective parameters are subject to judgment issues, i.e., people judge aspects related to their lives ${ }^{(2)}$. The concept of QOL in the health field emerged from a movement of humanization in the field toward the valorization of other parameters beyond symptoms and epidemiological data, such as the incidence and prevalence of diseases ${ }^{(3)}$.

The group who developed the World Health Organization Quality of Life Assessment ${ }^{(4)}$ defined QOL based on the perceptions of individuals concerning their positions in life. This group developed the WHOQOL-100 instrument to assess QOL from a cross- 
cultural perspective, with the collaboration of 15 centers from different countries ${ }^{(5)}$. Afterwards, it developed the WHOQOL-OLD module. Based on the WHOQOL-100 and following the same methodological approach, this module specifically assesses the elderly and should be used to complement the first ${ }^{(3)}$.

On the international scene, there has been an increased interest in assessing and improving the $\mathrm{QOL}$ of seniors and in concepts related to successful and active aging ${ }^{(6)}$. People age in different contexts. There are those aging in the community and those aging in Long Term Care (LTC) facilities. Seeking to analyze the aging process in different contexts and to support interventions implemented in health services that compose the healthcare network directed to the elderly, this study presents a comparison of the QOL of seniors living in two Brazilian regions. These regions were the study setting of a doctoral(7) dissertation, conducted in Porto Alegre, Rio Grande do Sul, Brazil and a Master's thesis conducted in both Porto Alegre and Santa Rita do Sapucaí, Minas Gerais, Brazil(8).

The population of those 60 years old and older for both Rio Grande do Sul and Minas Gerais was above the national Brazilian average. Both states also presented a similar life expectancy, 71.9 years old and 71.8 years old, respectively. In Brazil in 2010, of the 13,933,173 illiterate people, $39.2 \%$ were 60 years old or older ${ }^{(9)}$. The Brazilian regulations concerning healthcare ensures the right of older adults to live with their families in the community, though many still depend on LTC services due to cultural factors, fragile family arrangements, and availability of alternative services ${ }^{(10)}$.

Being transferred from home to a nursing care facility is a great challenge for seniors because they have to face a change, sometimes a radical change, in their lifestyle(11). Ideally, the environment of an LTC facility is stimulating and provides experiences that enable seniors to be active and independent, with a view to favor better QOL within the institutionalized context ${ }^{(12)}$.

Therefore, this study's guiding questions include: is there any difference in the perceptions of QOL between the older adults living in the community and those living in LTC facilities in the two Brazilian regions selected for this study? Do factors such as gender, age, schooling, self-reported health status, leisure activities, or number of children, influence these perceptions, when statistically controlled?

The interest in comparing the results reported by the studies previously mentioned emerged due to the high percentage of seniors in the studied states and the limited number of studies of this nature. There are few studies addressing QOL among the elderly in Brazil and even fewer studies comparing it in different living contexts.

\section{Method}

A search was conducted of secondary data based on epidemiological cross-sectional studies developed in Porto Alegre, Rio Grande do Sul in 2004 and in Pouso Alegre and Santa Rita do Sapucaí, Minas Gerais, Brazil in 2010. The first study setting was an urban district in Porto Alegre (Northwest health district) with the largest proportion of seniors in the city. There were 129,905 inhabitants in this region, according to the 2010 Census $^{(9)}$, that is, $9.28 \%$ of the city's population, of which $19.71 \%$ were seniors. With an area of $20.73 \mathrm{~km}^{2}$, the Northwest district presented a demographic density of 6,266.52 inhabitants per $\mathrm{km}^{2(9)}$. This region is very heterogeneous in terms of socioeconomic conditions. The study's probabilistic sample was composed of 292 seniors $^{(7)}$.

The study's second setting was the South of Minas Gerais in Pouso Alegre, with an urban area of $40.4 \mathrm{~km}^{2}$ and rural area of $504.9 \mathrm{~km}^{2}$. Its population in 2009 was composed of 127,974 inhabitants, 11,477 of which were seniors $(9.0 \%)^{(9)}$. The city of Santa Rita do Sapucaí has an area of $321 \mathrm{~km}^{2}$ and a population of 36,150 inhabitants in $2009 ; 3,522$ of these $(9.7 \%)$ were seniors aged 60 years old or older ${ }^{(9)}$. The sample of the second study was composed of 76 seniors. Data from the first study were collected through a household survey. Non-probabilistic sampling (quota sampling) (8) was used in the second study conducted in the LTC facilities. Both the studies included participants older than 60 years old, capable of answering the study's instruments independently (without any assistance), and used similar instruments, which allowed addressing socio-economic and demographic variables in addition to QOL.

QOL was assessed through the WHOQOL-Bref ${ }^{(5)}$. The instrument is a brief version of the WHOQOL-100 and contains 26 questions: two addressing general QOL and satisfaction with health and 24 representing each of the 24 facets that compose the original instrument. It is composed of four domains: Physical, Psychological, Social Relationships and Environment. The higher the score, the greater the QOL, though there is no cutoff point for its classifications ${ }^{(3)}$. 
The variables used from the databases included: gender, age, marital status, schooling, leisure activities, number of children, and self-reported health status. These variables have already been used in studies addressing the subject ${ }^{(13)}$. The four domains in the WHOQOL-Bref, in addition to the general question about $\mathrm{QOL}$, were used as variables to assess QOL.

Data were treated through the SPSS version 18.0 with descriptive analysis with absolute and relative frequencies, average and standard deviation. Person's Chi-square, Chi-square with continuity correction (when necessary), and Student's t-test were used to compare the proportions and averages of the studied variables between the two groups of seniors. Poisson regression with robust variance was also performed to compare the quality of life of seniors in the two groups. Domains 2 (Psychological) and 3 (Social Relationships) were dependent variables that compose the models because they obtained a maximum level of significance of $p<0.20$ in the bivariate analysis. The independents variables and variables of interest for the correlation were: being institutionalized (or not), socio-demographic data, and health variables that obtained a maximum level of significance of $p<0.20$ in the bivariate analysis. The level of significance adopted for the multivariate analysis was 0.05 , i.e., p-values $<0.05$ were considered statistically significant.

The projects were approved by the Institutional Review Boards at the Vale do Sapucaí University in Pouso Alegre, MG (process No. 1289/10) and the Federal University of São Paulo (process No. 0423/04). All the participants signed free and informed consent forms.

\section{Results}

The following socio-demographic and health profiles were identified among the study's participants (Table $1)$ : the predominant age groups, equality distributed $(42.7 \%)$ among the seniors in the community living in Rio Grande do Sul were 60 to 69 years old and from 70 to 79 years old. Individuals 80 years old or older predominated among the seniors living in LTC facilities in Minas Gerais (42.1\%). The average age of seniors in Rio Grande do Sul was 71.23 years old ( $S D \pm 7.51$ ), while the average age of institutionalized seniors was 76.5 years old ( $S D \pm 9.51)$ with $p<0.001$. The female gender was predominant $(67.4 \%)$ among the participants in Rio Grande do Sul, while a similar proportion (50\%) of men and women was found among the institutionalized individuals in Minas Gerais. In regard to education, we note that $44.3 \%$ of the seniors in Rio Grande do Sul had a college degree while $10.5 \%$ of the studied sample in Minas Gerais had the same level of education. Most (92.0\%) individuals in Rio Grande do Sul had some leisure activity, while only $48.7 \%$ of the seniors living in LTC facilities reported some leisure activity. A small difference between the two groups was found in the selfassessments of their health. Most considered themselves to be healthy: $81.1 \%$ of those living in the community and $72.4 \%$ of those living in LTC facilities in Minas Gerais. All the following variables in the association analysis presented statistically significant differences $(p<0.005)$ : a larger proportion of women, younger individuals, with higher levels of education, more leisure activities and better self-reported health status among those living in the community in Rio Grande do Sul.

Table 1 - Socio-demographic and health profiles of seniors living in Rio Grande do Sul and Minas Gerais, Brazil, 2012

\begin{tabular}{|c|c|c|c|c|c|}
\hline \multirow{2}{*}{ Socio-demographic and health variables } & \multicolumn{2}{|c|}{ Seniors in the community RS } & \multicolumn{2}{|c|}{ Institutionalized seniors MG } & \multirow{2}{*}{$\mathbf{P}$} \\
\hline & Total & $f \%$ & Total & f $\%$ & \\
\hline \multicolumn{6}{|l|}{ Age group (years) } \\
\hline $60-69$ & 123 & 42.7 & 20 & 26.3 & \multirow{3}{*}{$0.000^{*}$} \\
\hline $70-79$ & 123 & 42.7 & 24 & 31.6 & \\
\hline 80 or more & 42 & 14.6 & 32 & 42.1 & \\
\hline \multicolumn{6}{|l|}{ Gender } \\
\hline Male & 94 & 32.6 & 38 & 50.00 & \multirow{2}{*}{$0.005^{*}$} \\
\hline Female & 194 & 67.4 & 38 & 50.00 & \\
\hline \multicolumn{6}{|l|}{ Education } \\
\hline Illiterate/incomplete elementary & 64 & 22.4 & 61 & 80.30 & \multirow{3}{*}{$0.000^{*}$} \\
\hline Elementary/middle school & 127 & 44.3 & 7 & 9.20 & \\
\hline High school/college & 96 & 44.3 & 8 & 10.52 & \\
\hline \multicolumn{6}{|l|}{ Leisure } \\
\hline Yes & 265 & 92.0 & 37 & 48.70 & \multirow{2}{*}{$0.000^{*}$} \\
\hline No & 23 & 8.0 & 39 & 51.30 & \\
\hline
\end{tabular}


Table 1 - (continuation)

\begin{tabular}{|c|c|c|c|c|c|}
\hline \multirow{2}{*}{ Socio-demographic and health variables } & \multicolumn{2}{|c|}{ Seniors in the community RS } & \multicolumn{2}{|c|}{ Institutionalized seniors MG } & \multirow{2}{*}{$\mathbf{P}$} \\
\hline & Total & $f \%$ & Total & $f \%$ & \\
\hline \multicolumn{6}{|l|}{ Self-reported health status } \\
\hline Healthy & 231 & 81.1 & 55 & 72.40 & \\
\hline Sick & 54 & 18.9 & 21 & 27.60 & $0.134^{\dagger}$ \\
\hline Missing & 3 & 0 & 0 & 0 & \\
\hline
\end{tabular}

* Chi-square; + Chi-square with continuity correction; Level of significance $p<0.005$

The average number of children among seniors living in Rio Grande do Sul was 2.9 (SD \pm 1.88 ), while the average number of children among those living in Minas Gerais was 1.89 ( $S D \pm 3.10)$, also with statistically significant differences $(p<0.001)$.

Table 2 presents higher scores in the QOL domains 1 (Physical), 2 (Psychological), and 3
(Social Relationships) among the seniors living in the community in Rio Grande do Sul, though no statistically significance was found in domain 1 . The institutionalized seniors presented higher scores in domain 4 (Environment) and general QOL, again with no statistical significance.

Table 2 - Average and standard deviation of the QOL domains and general QOL on the WHOQOL-BREF for the elderly. Rio Grande do Sul and Minas Gerais, Brazil, 2012

\begin{tabular}{lcc}
\hline \multicolumn{1}{c}{ Domains and general QOL } & Seniors in the community RS & Institutionalized seniors in MG \\
\hline Domain 1 - Physical & $68.61(\mathrm{DP} \pm 18.26)$ & $63.60(\mathrm{DP} \pm 22.14)$ \\
Domain 2 - Psychological & $69.69(\mathrm{DP} \pm 15.33)$ & $65.19(\mathrm{DP} \pm 17.62)$ \\
Domain 3 - Social Relationships & $75.10(\mathrm{DP} \pm 17.27)$ & $67.87(\mathrm{DP} \pm 20.31)$ \\
Domain 4 - Environment & $65.09(\mathrm{DP} \pm 16.19)$ & $66.20(\mathrm{DP} \pm 15.42)$ \\
General QOL & $69.81(\mathrm{DP} \pm 19.01)$ & $6.002^{\dagger}$ \\
\hline
\end{tabular}

* Student's $t$ test; +Level of significance $\mathrm{P}<0.005$

Table 3 - Results of multiple linear regression for domain 2-Psychological of the WHOQOL BREF and variables of interest. Rio Grande do Sul and Minas Gerais, Brazil, 2012

\begin{tabular}{|c|c|c|c|}
\hline Variable & Difference in the score & Beta & $\mathbf{P}$ \\
\hline Being institutionalized & 3.550 & 0.090 & 0.143 \\
\hline Male gender & 2.426 & 0.073 & 0.132 \\
\hline Self-assessment: healthy & 11.201 & 0.286 & 0.000 \\
\hline \multicolumn{4}{|l|}{ Education } \\
\hline Illiterate/incomplete elementary school & 1.000 & - & - \\
\hline Completed elementary/middle school & 6.981 & 0.212 & 0.001 \\
\hline High school/college & 11.062 & 0.315 & 0.000 \\
\hline Leisure activity & 6.752 & 0.161 & 0.003 \\
\hline Age (in years) & 0.066 & 0.034 & 0.500 \\
\hline Number of children & 0.065 & 0.009 & 0.855 \\
\hline
\end{tabular}

$\mathrm{R}^{2}=0.23$

The regression model, in which the dependent variable was the Psychological domain, explained $23 \%$ of the variance in the psychological domain of QOL with the following variables of interest: institutionalization, gender, self-reported health status, education, leisure, age and number of children. The variables that contributed most, by order of influence, were: high school/college $(\beta=0.315 ; p=0.000)$, being healthy $(\beta=0.286 ; \quad p=0.000)$, completed elementary/middle school $(\beta=0.212 ; p=0.001)$ and leisure $(\beta=0.161$; $p=0.003)$. The remaining variables, including 'being institutionalized', were not statistically significant when controlled.

Elderly individuals with higher educational levels (high school or bachelor's degree and completed elementary school or middle school), who perceived themselves to be healthy and enjoyed leisure activities, perceived themselves to have a better $\mathrm{QOL}$ in this 
domain, with a score that ranged from 6 to 11 points above those who were illiterate or had not completed elementary school, of those who perceived themselves to be sick or had no leisure activity.

Table 4 presents the results of the regression using the Social Relationships domain as the dependent variable in relation to the variables of interest: institutionalization, gender, self-assessment of health, education, age, and number of children. The regression model explained $6.5 \%$ of variance in this domain. The variables of interest that contributed to explaining the model, by order of influence, were: completed elementary/middle school $(\beta=0.160 ; p=0.021)$, high school/college $(\beta=0.150 ; p=0.032)$ and age $(\beta=0.118$; $p=0.036)$. The remaining variables, including 'being institutionalized', were not statistically significant, when controlled. Those with a higher educational level perceived themselves to have a better QOL in the domain Social Relationships compared to those who were illiterate or had not completed elementary school (six points above, on average, among those who had completed high school or had a bachelor's degree and also six above among those who had completed elementary/middle school). Older seniors also perceived themselves to have a better QOL ( 0.25 points, on average, for each year of life) in this domain.

Table 4 - Results of multiple linear regression for Domain 3 - Social Relationships of the WHOQOL BREF and variables of interest. Rio Grande do Sul and Minas Gerais, Brazil, 2012

\begin{tabular}{lccc}
\hline \multicolumn{1}{c}{ Variable } & Difference in the score & Beta & \\
\hline Institutionalized & -2.657 & -0.059 & 0.383 \\
Male gender & 0.043 & 0.001 & 0.071 \\
Self-reported health condition: healthy & 3.163 & 0.190 \\
Schooling & & - & 0.160 \\
$\quad$ Illiterate/incomplete elementary school & 1.000 & 0.150 & 0.021 \\
Completed elementary/middle school & 6.033 & 0.065 & 0.032 \\
$\quad$ High school/college & 6.033 & 0.118 \\
Leisure activity & 3.110 & 0.279 \\
Age (years) & 0.259 & 0.036 \\
Number of children & 0.641 & 0.149 \\
\hline
\end{tabular}

$\mathrm{R}^{2}=0.065$

\section{Discussion}

Assessing QOL among the elderly is important to identifying satisfaction in this phase of life and helping to define local policy strategies. There are, however, few studies comparing the QOL of seniors living in LTC facilities and in the community in different scenarios. This study enabled the comparison of the QOL and perceptions of the studied seniors living in LTC facilities in Minas Gerais and those living in the community in Rio Grande do Sul, Brazil and also to assess the main social, demographic, economic and health characteristics that play a role in QOL.

We observed that the greater concentration of seniors 80 years old or older were institutionalized individuals. In a study conducted in Iran, $85 \%$ of the seniors living in the community were between the ages of 65 and 79 years old(14). In Brazil, a study comparing seniors living in LTC facilities and those living in the community corroborates data obtained in this study: $52.5 \%$ of the institutionalized seniors were 80 years old or older and $83.8 \%$ of the seniors living in the community were 60 to 79 years old(10).

The average age among seniors living in the community was below that observed among institutionalized seniors. The results reported by a study conducted in Korea, which is a developing country, were similar to those reported by this study ${ }^{(15)}$. In turn, a study conducted in Canada, a country that has experienced the aging process for a longer period, reports that the individuals living in LTC facilities are 10 years older on average ${ }^{(16)}$. We infer that advanced age is a strong predictor of institutionalization due to the risk of functional incapacity and the development of chronic diseases doubles with every decade(10).

There were more female seniors living in the community, Rio Grande do Sul, than males, in contrast with the context experienced by those institutionalized in Minas Gerais, where equal proportions of genders were observed. This last finding, however, actually differs from those identified in other LSIs ${ }^{(16-17)}$. Equal proportions of genders in the studied LTC facilities are a 
result of the local policy regulating these facilities, which are required to offer equal numbers of slots to both men and women. A study conducted in Korea compared the QOL of institutionalized seniors and that of seniors living in the community and reports a larger proportion of women in both contexts(15). The predominance of women among the elderly is an international reality, as studies conducted in Canada(17) and Germany ${ }^{(16)}$ confirm, especially for those at advanced ages ${ }^{(18)}$.

This context is not different in Brazil. A study conducted of 3,295 Brazilian LTC facilities (i.e. $92.8 \%$ of the facilities in the country in 2008) reports that $57.3 \%$ of residents were women ${ }^{(19)}$. Longevity among women is confirmed by the population pyramid of both developed and developing countries $^{(9-10)}$. There are various factors explaining this difference and we highlight the greater exposure of young individuals to mortality due to external causes, especially homicide and traffic accidents, in developing countries ${ }^{(10)}$.

In relation to education, we observed that the seniors living in Rio Grande do Sul are more educated than the institutionalized seniors living in Minas Gerais. Most of the institutionalized seniors worked in rural areas, which probably hindered their access to schools.

This study shows that the seniors living in Porto Alegre, Rio Grande do Sul have more leisure activities than those in Minas Gerais. Such a fact may be related to better availability of leisure opportunities in the first setting and non-adherence, on the part of the institutionalized seniors, to the activities offered by the studied facilities. The limited number of leisure activities, or even their absence, in LTC facilities is a factor that encourages or worsens sedentariness, compromising the seniors' functional capacity in addition to leading to depressive symptoms ${ }^{(20)}$. Leisure plays an important role in socialization, promoting the physical and mental health of elderly individuals(21).

The seniors living in the community had a better perception concerning their health conditions when compared with their institutionalized counterparts, though the difference was small. It is known that a negative self-assessment of health is a strong predictor of mortality, functional incapacity, and worse mental health among the elderly ${ }^{(22)}$. One determinant factor improving self-assessments of health is level of education, which eases the access to and acknowledgment of information concerning self-care ${ }^{(23)}$. This statement is confirmed by the characteristics of the seniors living in Rio Grande do Sul, who presented higher educational levels and selfreported better health conditions.
When the four domains and the general QOL were compared among seniors, higher scores were observed among those living in the community in domains 1 (Physical), 2 (Psychological) and 3 (Social Relationships), though only the second and third domains presented statistically significant differences. Studies conducted in Korea, Latin America and the USA comparing QOL between institutionalized and non-institutionalized seniors report results contrary to those found in this study concerning the psychological domain. These studies report better scores among those living in LTC facilities. It is possible that the individuals addressed in these studies achieved greater mental wellbeing, which alleviates depressive symptoms, due to friendships, certain sources of pleasure and socialization due to local conditions and/or socioeconomic and cultural factors ${ }^{(15)}$. Social participation is a strong indicator of wellbeing for seniors. It is believed that social isolation is linked to worse mental and physical health. Isolation may be identified among both institutionalized individuals and those living in the community, depending on the living conditions they are exposed to. It is also known that group activities satisfactorily contribute to seniors' self-esteem and autonomy ${ }^{(10)}$. It is important to stress that it is the role of LTC facility managers to devise strategies intended to encourage social relationships, such as cultural and leisure activities, as well as physical exercise, among the institutionalized seniors, since these individuals may have a perception of their QOL as being worse without such stimuli. Variables related to social participation can be included in other studies in order to confirm these inferences.

Seniors with more years of schooling reported statistically significant better indices of QOL in the multivariate analysis concerning the Psychological and Social Relationships domains. A study analyzing factors associated with health-related quality of life (HRQOL) in Iran also identified an association between a lower educational level and unhappiness and difficulties in social relationships among the elderly(14).

The variables in the multivariate analysis that explained the differences in the perceptions of QOL concerning the Psychological domain were perception of health and leisure. In studies addressing either seniors living in the community or institutionalized seniors and where factors associated with QOL were assessed also verified that a better self-assessment of health and the practice of leisure activities are related to an improved perception of $\mathrm{QOL}^{(20,24)}$, when linked to the Environment domain of the WHOQOL-Bref or the general average of 
the facets of the WHOQOL-OLD. Seniors usually have more free time to spend in social and mental activities. It is possible that when they are not properly stimulated or are not involved in activities and committed to objectives, they feel isolated, demotivated, and may have their emotional sphere compromised. Again, this situation may occur with both individuals living in the community and those who are in institutions.

We also note that the multivariate analysis of the Social Relationships domain presented an association with the variable 'age' $(p<0.05)$, which may be related to the fact that a senior's network of relationships tends to diminish with age. It is known that elderly individuals who have a more intense social life report better perceptions of $\mathrm{QOL}^{(3)}$. The association of variables was weak in the multivariate analysis of the Social Relationships domain and the regression model explained only $6.5 \%$ of the variance in the domain.

We note that when these variables of interest were controlled through multiple linear regression, being institutionalized or living in the community did not present statistically significant differences in the QOL indexes. International studies identified differences between the perceptions of QOL in both contexts(15). It seems that these individuals' prior social lives, and economic and health conditions are the factors that most influence their perceptions of their QOL. These findings also reinforce the aging process as being heterogeneous.

\section{Conclusion}

Being institutionalized or living in the community in the studied regions did not influence QOL in the analysis models. In turn, factors such as age, education, selfassessment of health and leisure activities, when statistically controlled, influenced the studied seniors' perceptions of their QOL. The institutionalized individuals living in Minas Gerais reported, in general, a lower QOL because they were older and experienced worse socioeconomic and health conditions than did their counterparts. Nursing assessments and interventions should be implemented in the context of primary health care and LSIs, taking into account these differences in order to promote QOL in this age group. Other variables of interest can be investigated to identify factors that contribute to these individuals' QOL perceptions in addition to those addressed in this study.

\section{References}

1. Zhan L. Quality of life: conceptual and measurement issues. J Adv Nurs. 1992 Jul;17(7):795-800.
2. Farquhar M.Eldery people's definitions of quality of life. Soc Sci Med. 1995 Nov;41(10):1439-46.

3. Fleck MP, Chachamovich E, Trentini C. Development and validation of the Portuguese version of the WHOQOL-OLD module. [português]. Rev Saúde Pública. 2006;40(5):785-91.

4. The Whoqol Group. The World Health Organization Quality of Life Assesssment WHOQOL): position paper from the World Health Organization. Soc Sci Med. 1995;41(10):1403-9.

5. Fleck MP, Louzada S, Xavier M, Chachamovich E, Vieira G, Santos L, Pinzon V. Aplicação da versão em português do instrumento de avaliação da qualidade de vida da Organização Mundial da Saúde "WHOQOL-100". Rev Saúde Pública. abril 1999;33(2):198-205.

6. Zaninotto P, Falaschetti E, Sacker A. Age trajectories of quality of life among older adults: results from the English Longitudinal Study of Ageing. Qual Life Res. 2009;18:1301-9. DOI 10.1007/s11136-009-9543-6.

7. Paskulin L, Molzahn AE. Quality of life of older adults in Brazil and Canada. West J Nurs Res. 2007 Feb;29(1):1026.

8. Vitorino LM, Vianna LAC. Coping religioso e espiritual de idosos institucionalizados. Acta Paul Enferm. 2012(8). In Press.

9. Instituto Brasileiro de Geografia e Estatística, 2010. [acesso 18 maio 2010]; Disponível em: www.ibge.gov. br/.../

10. Del Duca GF, Silva SG, Thumé E, Santos IS, Hallal PC. Predictive factors for institutionalization of the elderly: a case-control study. Rev Saúde Pública. [periódico na Internet]; fev 2012; [acesso 28 maio 2012];46(1). Disponível em: http://dx.doi.org/10.1590/S003489102012000100018

11. Araújo CLO, Ceolim MF. Sleep quality of elders living in long-term care institutions. Rev Esc Enferm USP. [periódico na Internet];2010; [acesso $2 \mathrm{dez}$ 2011];44(3):615-22. Disponível em: http://www.scielo. $\mathrm{br} / \mathrm{pdf} /$ reeusp/v44n3/10.pdf .

12. Almeida AJPS, Rodrigues VMCP. The quality of life of aged people living in homes for the aged. Rev. Latino-Am. Enfermagem. [periódico na Internet];novdez 2008; [acesso 15 mar 2012];16(6):1025-31. Disponível: $\quad$ http://dx.doi.org/10.1590/S010411692008000600014.

13. Alexandre TS, Cordeiro RC, Ramos LR. Factors associated to quality of life in active elderly. Rev Saúde Pública. [periódico na Internet]; maio 2009; [acesso 13 ago 2012];43(4):613-21.Disponível em: http://dx.doi. org/10.1590/S0034-89102009005000030. 
14. Tajvar M, Arab M, Montazeri A. Determinants of health-related quality of life in elderly in Tehran, Iran. BMC Public Health. [periódico na Internet]; set 2008; [acesso 25 fev 2012];8:323 Disponível em: http://www. biomedcentral.com/1471-2458/8/323.

15. Kim HS, Harada K, Miyashita M, Lee EA, Park JK, Nakamura $Y$. Use of Senior Center and the HealthRelated Quality of Life in Korean Older Adults. J Prevent Med Public Health. [periódico na Internet];jul 2011; [acesso 5 ago 2012];44(4):149-56. Disponível em: http://dx.doi.org/10.3961/jpmph.2011.44.4.149.

16. Robichaud L, Durand PJ, Bédard R, Ouellet JP.Quality of life indicators in long term care:Opinions of elderly residents and their families. Can J Occup Ther.2006 Oct; 73(4):245-51.

17. Onder G, Liperoti R, Soldato M, Carpenter I, Steel K, Bernabei $R$, et al. Case management and risk of nursing home admission for older adults in home care: results of the Aged in Home Care Study. J AM Geriatr Soc. 2007 Mar;55(3):439-44.

18. Hunger $M$, Thorand $B$, Schunk $M$, Döring $A$, Menn $P$, Peters A, Holle R. Multimorbidity and health-related quality of life in the older population: results from the German KORA-Age study. Health Qual Life Outcomes. July $2011 ; 9: 53$.

19. James BD, Bennett DA, Boyle PA, Leurgans S, Schneider JA. Dementia from Alzheimer Disease and Mixed Pathologies in the Oldest Old. JAMA. 2012 May 2;307(17):1798-800.

20. Gonçalves LHT, Silva AH, Mazo GZ, Benedetti TRB, Santos SMA, Marques $S$, et al. Institutionalized elderly: functional capacity and physical fi tness. Cad Saúde Pública. [periódico na Internet]; set 2010; [acesso 18 ago 2012];26(9):1738-46. Disponível em: http://www. scielo.br/pdf/csp/v26n9/07.pdf.

21. Parmelee PA, Harralson TL, Smith LA, Schumacher HR. Necessary and Discretionary Activities in Knee Osteoarthritis: do they mediate the Pain-Depression relationship? Am Acad Pain Med. Jul-Aug;8(5):449-61. 22. Balboa-Castillo T, León-Muñoz LM, Graciani A, RodríguezArtalejo F, Guallar-Castillón P. Longitudinal association of physical activity and sedentary behavior during leisure time with health-related quality of life in communitydwelling older adults. Health Qual Life Outcomes. [periódico na Internet]; 2011 June; [acesso 2 ago 2012];9:47. Disponível em: http://www.hqlo.com/content/9/1/47.

23. Pagotto $V$, Nakatani AYK, Silveira EA. Factors associated with poor self-rated health in elderly users of the Brazilian Unified National Health System. Cad Saúde Pública. ago 2011;27(8):1593-602.
24. Estrada A, Cardona D, Segura AM, Chavarriaga LM, Ordóñez J, Osório J]. Calidad de vida de los adultos mayores de Medellín. Biomédica. 2011 Dec;31:492-502.
Received: Aug. 20 th 2012 Accepted: Oct. $1^{\text {st }} 2012$ 